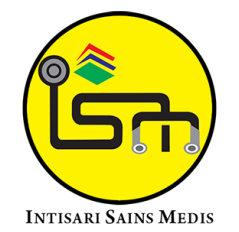

Published by Intisari Sains Medis

\title{
Interpretasi nilai Cycle Threshold (CT) Reverse Transcriptase-Polymerase Chain Reaction (RT-PCR) SARS-CoV-2 pada pasien hamil dengan uji antibodi SARS-CoV-2 positif dan COVID-19 asimtomatik
}

\author{
Ni Wayan Candrawati ${ }^{1 *}$, William Ray Cassidy ${ }^{1}$
}

'Departemen Pulmonologi dan IImu Kedokteran Respirasi, Fakultas Kedokteran, Universitas Udayana, RSUP Sanglah, Bali, Indonesia

\section{*Korespondensi:}

Ni Wayan Candrawati; Departemen Pulmonologi dan IImu Kedokteran Respirasi, Fakultas Kedokteran, Universitas Udayana, RSUP Sanglah, Bali, Indonesia; niwayancandrawati@gmail.com

\section{Diterima: 26-08-2021}

Disetujui:30-10-2021

Diterbitkan: 09-11-2021

\section{ABSTRACT}

Background: The majority of pregnant women with COVID-19 will be asymptomatic throughout the disease period. SARS-CoV-2 antibody tests were utilized as a screening tool for patients giving birth in a hospital. Cycle Threshold (CT) value in asymptomatic pregnant women may guide patient management and isolation protocol.

Methods: Research data were obtained from medical records from March until October 2020 with a total sampling method. Pregnant women with positive SARS-CoV-2 antibody and asymptomatic COVID-19 were included. CT-value based on gene primers were grouped and analyzed by Microsoft Excel 365 for Windows.

Keywords: Asymptomatic COVID-19, Pregnancy, CT-value Cite This Article: Candrawati, N.W., Cassidy, W.R. 2021.Interpretasi nilai Cycle Threshold (CT) Reverse TranscriptasePolymerase Chain Reaction (RT-PCR) SARS-CoV-2 pada pasien hamil dengan uji antibodi SARS-CoV-2 positif dan COVID-19 asimtomatik. Intisari Sains Medis 12(3): 822-827. D0I: 10.15562/ism.v12i3.1184

\section{ABSTRAK}

Latar Belakang: Mayoritas pasien COVID-19 dengan kehamilan tidak bergejala sepanjang periode perjalanan penyakit. Uji antibodi SARS-CoV-2 sempat digunakan sebagai alat skrining pasien yang akan melahirkan di rumah sakit. Nilai Cycle Threshold (CT) pada pasien hamil dengan COVID-19 asimtomatik kemungkinan dapat memandu tatalaksana dan isolasi pasien.

Metode: Penelitian ini menggunakan data sekunder rekam medis dari bulan Maret hingga Oktober 2020 dengan total sampling. Data pasien hamil dengan uji antibodi SARS-CoV-2 positif dan terkonfirmasi COVID-19 asimtomatik dianalisis. Nilai cycle threshold (CT-value) berdasar primer dikelompokkan dan
Results: Twenty-five pregnant women with asymptomatic COVID-19 fulfilled the inclusion criteria. All patients had positive SARS-CoV-2 antibodies. The highest and lowest CT-value for the RdRp gene were 37.91 and 26.90, followed by N-gene (34.37 and 32.16), E-gene (38.36 and 27.60), helicase gene (35.65 and 24.29), ORF1a (35.87 and 26.80), and ORF1ab (41.28 and 27.82).

Conclusion: SARS-CoV-2 antibody test is not a recommended screening tool as it can reveal past infection or immunity to SARS-CoV-2. CT-value is incapable of determining COVID-19 severity and infection period.
Kata Kunci: COVID-19 Asimtomatik, Kehamilan, Nilai CT

Cite This Article: Candrawati, N.W., Cassidy, W.R. 2021.Interpretasi nilai Cycle Threshold (CT) Reverse TranscriptasePolymerase Chain Reaction (RT-PCR) SARS-CoV-2 pada pasien hamil dengan uji antibodi SARS-CoV-2 positif dan COVID-19 asimtomatik. Intisari Sains Medis 12(3): 822-827. D0I: 10.15562/ism.v12i3.1184 


\section{PENDAHULUAN}

Pada akhir bulan Desember tahun 2019, dilaporkan kasus pneumonia yang tidak diketahui penyebabnya di Tiongkok. Angka kasus pneumonia baru tersebut terus meningkat hingga dan sebagian besar kasus terkait dengan kunjungan ke pasar hewan (Live Market) di Wuhan, Provinsi Hubei, Tiongkok. ${ }^{1}$ Pada sampel isolat pasien didapatkan adanya infeksi oleh Coronavirus, jenis betacoronavirus tipe baru. World Health Organization (WHO) secara resmi memberi nama virus baru tersebut sebagai Severe Acute Respiratory Syndrome Coronavirus-2 (SARS-CoV-2) dan penyakitnya sebagai Coronavirus Disease 2019 (COVID-19) pada tanggal 11 Februari 2020. Jumlah kasus semakin meningkat dengan konfirmasi terjadinya human-to-human transmission. Pada tanggal 11 Maret 2020 WHO mengumumkan bahwa COVID-19 menjadi pandemi global bahkan hingga di Indonesia. ${ }^{1-3}$

Baku emas uji diagnostik COVID-19 adalah melalui uji asam nukleat (Nucleic Acid Testing/NAT) dengan ReverseTranscription Polymerase Chain Reaction (RT-PCR). Pemeriksaan RT-PCR sangat spesifik tetapi sensitivitasnya bergantung kepada jumlah virus, replikasi virus, metode isolasi RNA, serta sumber dan waktu pengambilan sampel terkait dengan fase penyakit. ${ }^{4}$ Pengambilan spesimen guna uji diagnostik COVID-19 yang direkomendasikan adalah melalui swab nasofaring dan orofaring, atau dari sampel saluran nafas bagian bawah pada kelompok pasien yang menggunakan ventilator mekanik invasif. ${ }^{4}$

Selama periode 2 bulan pandemi COVID-19 di Tiongkok awal tahun 2020 tercatat 72.314 kasus COVID-19. Pemeriksaan molekuler hanya dilakukan pada $44.672(62,00 \%)$ kasus dengan bahan uji swab tenggorok. ${ }^{5}$ Sebanyak 889 kasus asimtomatik terdiagnosis melalui hasil uji asam nukleat virus positif, tanpa gejala khas seperti demam, batuk kering, dan rasa lelah. Pada saat itu seluruh pasien yang terkonfirmasi COVID-19 diisolasi dalam rumah sakit di Tiongkok, tanpa memandang derajat penyakitnya. ${ }^{5}$

Penyebaran SARS-CoV-2 yang luas ditengarai melibatkan penderita COVID-19 yang tidak bergejala tetapi sebenarnya infeksius. Data epidemiologi yang ada membuat tenaga kesehatan berusaha mencari tahu bukti laboratoris dari pemikiran tersebut. ${ }^{6}$

Nilai Cycle Threshold atau CT merupakan jumlah siklus yang dibutuhkan sampai sinyal fluoresens pada alat uji melewati nilai ambang (threshold). ${ }^{7}$ Pasien akan dinyatakan positif terinfeksi SARSCoV-2 serta menderita COVID-19 apabila melalui hasil RT-PCR diperoleh nilai CT di bawah nilai ambang, yang berbeda-beda tergantung pada alat pemeriksaan yang digunakan. Nilai CT secara proporsional akan berbanding terbalik dengan jumlah target asam nukleat dalam sampel, yang berarti semakin rendah nilai CT maka semakin banyak jumlah asam nukleat yang terdeteksi. ${ }^{7,8}$

Penelitian awal yang mendukung konsistensi teori tersebut pada pemeriksaan SARS-CoV-2 menunjukkan bahwa setiap peningkatan nilai CT sebesar 3,3 akan setara dengan penurunan jumlah asam nukleat sebesar 10 kali lipat. ${ }^{9}$ Ketika periode awal infeksi, umumnya pasien memiliki nilai CT yang lebih kecil berkisar 20 - 30 atau bahkan kurang. Seiring dengan respon imun alamiah terhadap infeksi virus, maka nilai CT akan berangsur meningkat, merefleksikan jumlah asam nukleat dari virus yang semakin sedikit. ${ }^{10}$

Durasi isolasi pasien menjadi permasalahan yang menimbulkan dilema bagi klinisi. Apabila pasien dinyatakan selesai isolasi terlalu dini, akan muncul potensi peningkatan penyebaran penyakit yang semakin luas. Di sisi lain, pemanjangan masa isolasi yang sebenarnya belum tentu diperlukan juga menimbulkan berbagai dampak negatif. Pasien akan merasa frustasi/ depresi karena semakin menjauhkan pasien dari hubungan sosial, masa isolasi yang diperpanjang tentu menghabiskan ketersediaan stok alat pelindung diri, dapat menunda prosedur medis, mengurangi jumlah ruangan isolasi yang tersedia, menambah ketidaknyamanan pasien akibat prosedur swab nasofaring yang terus diulang. ${ }^{8}$

Dalam menghadapi penyakit menular, populasi rentan perlu mendapatkan perhatian khusus. Wanita hamil memiliki risiko kematian yang tinggi ketika epidemi SARS dan MERS dua dekade lalu, tercatat sepertiga dari wanita hamil yang terinfeksi meninggal dunia. ${ }^{11}$ Akan tetapi, data epidemiologi menunjukkan hasil yang kontradiktif dengan dugaan tersebut. Hingga saat ini, belum terdapat bukti empiris bahwa populasi ibu hamil lebih rentan terinfeksi SARS-CoV-2. Sebagian besar wanita hamil yang terinfeksi SARSCoV-2 tidak mengalami gejala klinis. Pada kelompok pasien hamil dengan gejala COVID-19, sebagian besar mengalami gejala derajat ringan atau sedang seperti gejala flu. ${ }^{12}$ Oleh karena itu, penelitian bertujuan untuk mengetahui interpretasi nilai CT Reverse Transcriptase-Polymerase Chain Reaction (RT-PCR) SARS-CoV-2 pada pasien hamil dengan uji antibodi SARS-CoV-2 positif dan COVID-19 asimtomatik.

\section{METODE}

Penelitian ini adalah penelitian deskriptif dengan menggunakan pendekatan potong lintang yang dilaksanakan di RSUP Sanglah yang memiliki ketika bulan Maret 2020 - Oktober 2020. Penentuan besar sampel dilakukan dengan metode Total Sampling, dalam penelitian ini yang menjadi sampel adalah semua pasien terkonfirmasi COVID-19 tanpa gejala (asimtomatis) terdiagnosis melalui hasil RT-PCR swab nasofaring dan orofaring positif di RSUP Sanglah yang berusia lebih dari 18 tahun dengan kehamilan dan dirawat di RSUP Sanglah periode bulan Maret 2020 sampai Oktober 2020. Kriteria inklusi penelitian ini adalah pasien hamil dengan hasil RT-PCR swab nasofaring dan orofaring SARS-CoV-2 positif tanpa gejala klinis dan memiliki hasil antibodi terhadap SARS-CoV-2 positif. Variabel variabel penelitian yang diteliti antara lain jenis kelamin, usia, riwayat pekerjaan, daerah tempat tinggal saat ini, dan nilai CT dari pemeriksaan RT-PCR swab nasofaring dan orofaring SARS-CoV-2. Catatan rekam medik tidak ditemukan atau tidak lengkap, serta pasien - pasien dengan gejala klinis COVID-19 demam, batuk, pilek, sesak nafas, nyeri dada, nyeri kepala, nyeri otot dan sendi, mual, muntah, diare, lemas, gangguan indra penciuman, gangguan indera pengecapan tidak dimasukkan dalam penelitian.

Primer yang dipergunakan guna mendeteksi protein SARS-CoV-2 di 
lokasi penelitian berbeda-beda tergantung ketersediaan paket reagen. Terdapat berbagai target primer pada penelitian ini, yaitu primer terhadap gen Spike (S), gen Nucleocapsid (N), gen Envelope (E), gen RNA-dependent RNA polymerase (RdRp), protein helicase, dan Open Reading Frame 1a (ORF1a) serta Open Reading Frame lab (ORF1ab). Jenis - jenis kit reagen untuk pemeriksaan RT-PCR SARS-CoV-2 dalam penelitian ini adalah: 1) Allplex ${ }^{\text {m }}$ 2019-nCoV Assay, deteksi gen RdRp, gen $\mathrm{N}$, gen $\mathrm{E}$, nilai titik potong $\leq 40$ untuk hasil RT-PCR positif; 2) DiaPlexQ ${ }^{\text {tw }}$ Novel Coronavirus (2019-nCoV) Detection Kit, deteksi ORF1a dan gen N, nilai titik potong $\leq$ untuk hasil RT-PCR positif; 3) M-BioCoV-19 RT-PCR Kit, deteksi gen $\mathrm{RdRp}$ dan protein helicase, nilai titik potong $<40$ untuk hasil RT-PCR positif; dan 4) SD BIOSENSOR STANDARD M nCoV Real-Time Detection kit, deteksi ORFlab dan gen E, nilai titik potong $\leq 36$ untuk hasil RT-PCR positif. ${ }^{13-16}$

Pasien dikategorikan sebagai suspek COVID-19 melalui skrining universal yang dilakukan baik dalam rumah sakit maupun di fasilitas kesehatan lainnya. Metode skrining yang digunakan selama periode penelitian adalah uji cepat antibodi terhadap SARS-CoV-2. Penanda serologis yang diperiksakan adalah imunoglobulin M (IgM), imunoglobulin G ( $\operatorname{IgG}$ ) atau imunoglobulin yang tidak spesifik. Seluruh data yang telah terkumpul ditabulasikan, diolah dan dianalisis secara deskriptif dengan menggunakan perangkat lunak Microsoft Excel 365 untuk Windows.

\section{HASIL}

Dari data seluruh pasien wanita hamil yang terkonfirmasi COVID-19 sepanjang bulan Maret 2020 hingga Oktober 2020 diperoleh sejumlah 25 wanita hamil dengan COVID-19 asimtomatik. Rerata usia pasien adalah 26,48 $\pm 5,30$ tahun. Sebagian besar pasien $(72,0 \%)$ diketahui memiliki aktivitas harian sebagai ibu rumah tangga. Sebanyak 7 orang pasien (28\%) memiliki mata pencaharian tetap, walaupun tidak semuanya masih bekerja di kala pandemi ini. Pasien yang sebelumnya bekerja di sektor esensial sebagai kasir apotek $(4,0 \%)$ ternyata telah 2 bulan tidak aktif bekerja. Distribusi para pekerja meliputi pegawai hotel $(4,0 \%)$, terapis spa $(4,0 \%)$, pramusaji $(4,0 \%)$, dan pegawai swasta $(8,0 \%)$ juga telah tidak bekerja semasa pandemi.

Berdasarkan domisilinya, diketahui sebanyak 9 pasien $(36,0 \%)$ berdomisili di Denpasar, kemudian diikuti dengan Klungkung dan Bangli masing-masing 1 pasien $(4,0 \%)$, Nusa Dua $(8,0 \%)$, Badung sebanyak 4 pasien (16\%), Gianyar 6 pasien (24\%), dan Karangasem 2 pasien (8\%) (Tabel 1). Riwayat kontak erat dengan pasien terkonfirmasi COVID-19 tidak diketahui oleh semua pasien.

Hasil penelitian menunjukkan bahwa nilai CT paling tinggi sebesar 41,28 pada ORF1ab dan nilai CT paling rendah sebesar 17,66 pada gen N. Di antara sampel dengan IgM dan IgG positif terhadap SARS-CoV-2, nilai CT terendah terdeteksi pada gen $\mathrm{N}(17,81)$ dan nilai CT

\section{Tabel 1. Karakteristik data pasien wanita hamil terkonfirmasi COVID 19
asimtomatis di RSUP Sanglah Denpasar bulan Maret 2020 - Oktober \\ Tabel 1. Karakteristik data pasien wanita hamil terkonfirmasi COVID 19
asimtomatis di RSUP Sanglah Denpasar bulan Maret 2020 - Oktober 2020}

\begin{tabular}{|c|c|c|c|}
\hline Variabel & $\mathrm{N}=25$ & Minimum-Maksimum & Rerata \pm SB \\
\hline Umur (Tahun) & & & $26,48 \pm 5,30$ \\
\hline \multicolumn{4}{|l|}{ Pekerjaan, n (\%) } \\
\hline Ibu Rumah tangga & $18(72,0)$ & & \\
\hline Pegawai Swasta & $2(8,0)$ & & \\
\hline Pramusaji & $1(4,0)$ & & \\
\hline Kasir Apotek & $1(4,0)$ & & \\
\hline Pengasuh Anak & $1(4,0)$ & & \\
\hline Terapis Spa & $1(4,0)$ & & \\
\hline Pegawai Hotel & $1(4,0)$ & & \\
\hline \multicolumn{4}{|l|}{ Domisili, n (\%) } \\
\hline Denpasar & $9(36,0)$ & & \\
\hline Badung & $4(16,0)$ & & \\
\hline Gianyar & $6(24,0)$ & & \\
\hline Klungkung & $1(4,0)$ & & \\
\hline Bangli & $1(4,0)$ & & \\
\hline Karangasem & $2(8,0)$ & & \\
\hline Nusa Dua & $2(8,0)$ & & \\
\hline \multicolumn{4}{|l|}{ Nilai CT } \\
\hline Gen ORF1ab & & $27,82-41,28$ & \\
\hline Gen $N$ & & $26,80-35,87$ & \\
\hline $\mathrm{RdRp}$ & & $26,90-37,91$ & \\
\hline Allplex RdRp & & $34,01-37,49$ & \\
\hline Gen E & & $27,60-38,36$ & \\
\hline Gen ORF1a & & $26,80-35,87$ & \\
\hline N Diaplexq & & $17,66-26,61$ & \\
\hline M-Biocov Rppp30 & & $22,48-29,43$ & \\
\hline Gen Helicase & & $24,29-35,65$ & \\
\hline
\end{tabular}

tertinggi terdeteksi pada ORF1ab $(41,28)$. Di antara sampel dengan IgM positif terhadap SARS-CoV-2, nilai CT terendah terdeteksi pada gen $\mathrm{N}(17,66)$, dan nilai $\mathrm{CT}$ tertinggi terdeteksi pada ORF1ab $(35,79)$. Di antara sampel dengan IgG positif terhadap SARS-CoV-2 dan 1 sampel dengan Imunoglobulin tidak spesifik, nilai CT terendah terdeteksi pada gen $\mathrm{N}(18,00)$ dan nilai CT tertinggi terdeteksi pada gen $\operatorname{RdRp}(36,29)$ (Tabel 1).

\section{PEMBAHASAN}

Nilai tengah periode inkubasi SARSCoV-2 adalah 5 hari, dengan rentang antara $2-7$ hari. RNA virus dapat dideteksi pada saluran napas $2-3$ hari sebelum muncul gejala, mencapai kadar puncak saat awitan simtom, dan menurun
Variabel 
dalam periode 7 - 8 hari pada kebanyakan pasien. Rekomendasi dari WHO dan CDC mengenai definisi pasien COVID-19 dapat dinyatakan bebas dari virus dengan setidaknya 2 hasil RT-PCR negatif membuat sebagian pasien menjalani periode isolasi yang terlalu lama, mulai dari hitungan minggu hingga bulan. Deteksi RNA yang lebih lama cenderung terdapat pada pasien dengan gejala berat, akan tetapi hal serupa juga dapat terjadi pada pasien dengan gejala ringan atau asimtomatik. Durasi positivitas PCR yang lebih lama dijumpai di saluran napas bawah dan feses. ${ }^{8}$

Nilai CT saat awal infeksi biasanya sebesar 20-30 atau kurang, dan cenderung meningkat setelahnya, merefleksikan berkurangnya jumlah RNA virus karena peran dari sistem imun tubuh. Penting untuk diketahui bahwa nilai CT tidak mencerminkan beban virus yang sesungguhnya, yang memerlukan standarisasi dengan kurva referensi. Oleh karena itu, nilai CT tidak dapat dibandingkan secara langsung antar uji. Variasi dari hasil RT-PCR juga dapat dipengaruhi oleh kualitas pengambilan spesimen. ${ }^{8}$

Deteksi RNA melalui RT-PCR tidak secara langsung dapat diartikan menjadi virus viabel yang infeksius. Pecahan RNA subgenomik berkaitan secara erat dengan vesikel intraseluler yang melindungi RNA dari degradasi oleh enzim-enzim tubuh inang. Parameter infektivitas SARSCoV-2 yang baik adalah melalui kultur seluler, akan tetapi kultur virus hanya dapat dilakukan di laboratorium tertentu sesuai standar keamanan biologis sehingga tidak digunakan dalam praktik seharihari. Bukti-bukti klinis menunjukkan kombinasi jangka waktu dari awitan gejala dan nilai CT bermanfaat untuk memprediksi infektivitas. ${ }^{8}$

Hasil RT-PCR SARS-CoV-2 yang positif persisten disebabkan karena residu tubuh virus, bukan karena virus yang masih memiliki kemampuan replikasi. Sebuah penelitian di Perancis memeriksa 183 sampel dengan hasil PCR positif dan 129 sampel berhasil diinokulasi dalam kultur seluler. Sampel dengan nilai CT 1317 membuahkan hasil kultur virus positif, dan tidak ada virus yang berhasil dikultur pada sampel dengan nilai CT $\geq 34$. Hasil uji PCR tetap positif sampai dengan 20 hari setelah awitan gejala, tetapi tidak dapat dilakukan kultur virus yang viabel setelah hari ke-8. Penelitian di Singapura memperoleh hasil kultur positif dari 14 sampel dengan total 73 sampel. Kultur virus tidak berhasil dari seluruh sampel dengan nilai CT > 30, dan 90\% dari keseluruhan sampel yang diambil setelah hari ke-14 dari awitan memiliki nilai CT $>30{ }^{8}$ Berdasarkan hasil dari beberapa studi terdahulu maka dapat disimpulkan sebagian besar pasien dalam penelitian ini berada dalam periode infeksius, dimana terdapat kemungkinan virus viabel yang dapat memunculkan hasil kultur virus positif.

Apabila ditinjau dari segi pemeriksaan serologis, IgM dan IgG terhadap SARSCoV-2 mulai diproduksi oleh tubuh dalam 1 - 2 minggu paska awitan gejala. Kadar IgM terhadap protein $\mathrm{N}$ terdeteksi hari ke-1 - 7, sebagian besar serokonversi dalam kurun waktu 14 hari, kemudian IgM menurun drastis di hari ke-20, dan tidak terdeteksi setelah 60 hari. IgG mulai terdeteksi di hari ke-7 hingga ke-14 paska awitan gejala dan mampu bertahan jauh lebih lama dari IgM. ${ }^{17}$ Dari kelompok pasien dengan hasil IgM positif, 2 sampel memiliki nilai CT kurang dari 30, menandakan kemungkinan pasien masih berada dalam periode infeksi akut dan probabilitas tinggi untuk menularkan. Sebanyak 10 sampel dengan hasil IgG positif dan imunoglobulin tidak spesifik memiliki nilai CT kurang dari 30 dan 3 sampel dengan nilai CT lebih dari 30. Temuan ini bermakna bahwa pasien sudah berada dalam periode konvalesen tetapi tidak menutup kemungkinan apabila dilakukan kultur virus maka bisa diperoleh hasil positif. Sebanyak 10 sampel dengan hasil IgG positif dan imunoglobulin tidak spesifik memiliki nilai CT kurang dari 30 dan 3 sampel dengan nilai CT lebih dari 30. Temuan ini bermakna bahwa pasien sudah berada dalam periode konvalesen tetapi tidak menutup kemungkinan apabila dilakukan kultur virus maka bisa diperoleh hasil positif.

Sampai saat ini, belum terdapat bukti yang cukup kuat untuk menggambarkan bahwa populasi ibu hamil lebih rentan terinfeksi SARS-CoV-2. Sebagian besar wanita hamil yang terinfeksi SARS-CoV-2 tidak mengalami gejala klinis. Pada kelompok pasien hamil dengan gejala
COVID-19, sebagian besar mengalami gejala derajat ringan atau sedang seperti gejala flu. Penelitian dengan lebih dari 64.000 wanita hamil dengan COVID-19 menunjukkan hasil gejala klinis yang paling sering ditemukan antara lain batuk $(41,00 \%)$, demam $(40,00 \%)$, sesak nafas $(21,00 \%)$, mialgia $(19,00 \%)$, gangguan indra pengecapan $(14,00 \%)$ dan diare $(8,00 \%) .{ }^{12}$

Dari 1.219 pasien hamil dengan COVID-19, sebanyak 47\% asimtomatik. Pemeriksaan RT-PCR SARS-CoV-2 dilakukan atas dasar skrining sebelum melahirkan di rumah sakit. Wanita hamil dengan gejala berat hingga kritis memiliki peningkatan risiko kelahiran dengan seksio caesaria, hipertensi saat kehamilan, dan kelahiran preterm. ${ }^{18}$

Gejala klinis yang berat lebih kerap dijumpai saat usia kehamilan lanjut, seperti ketika trimester ke-3 atau peripartum. Ibu hamil dengan COVID-19 tidak memiliki peningkatan risiko kelahiran preterm. Alasan utama rawat inap pada ibu hamil dengan COVID-19 asimtomatik adalah untuk melahirkan, sedangkan bagi pasien bergejala indikasi rawat inap bertambah karena gejala klinis COVID-19 itu sendiri. Faktor risiko yang terkait dengan terinfeksi SARS-CoV-2 dan perawatan di rumah sakit karena COVID-19 antara lain: 1) Etnis kulit hitam, asia, atau minoritas lain; 2) Indeks Massa Tubuh (IMT) $>25 \mathrm{~kg} /$ $\mathrm{m}^{2}$; 3) Komorbiditas sebelum kehamilan seperti diabetes atau hipertensi; 4) Usia ibu 35 tahun atau lebih; dan 5) Tinggal di area dengan kondisi sosioekonomi buruk. ${ }^{12}$

Tingkat mortalitas pada wanita hamil dengan COVID-19 jauh lebih tinggi jika dibandingkan dengan kasus kematian ibu hamil tanpa COVID-19. Persentase kasus ibu hamil dengan COVID-19 bergejala yang memerlukan perawatan di ruang intensif lebih tinggi, akan tetapi hal tersebut dapat dipengaruhi ambang klinis yang lebih rendah dibandingkan dengan pasien hamil tanpa COVID-19, sehingga tidak dapat serta-merta menggambarkan gejala klinis lebih berat pada ibu hamil dengan COVID-19. Wanita hamil dengan COVID-19 asimtomatik dapat menjalani isolasi mandiri. Bagi pasien hamil yang telah menyelesaikan masa isolasi mandiri COVID-19, tidak ada perbedaan tatalaksana saat akan melahirkan. ${ }^{12}$ 
Persentase wanita hamil yang terdiagnosis COVID-19 melalui skrining universal lebih rendah dibandingkan dengan wanita hamil yang terdiagnosis COVID-19 melalui gejala klinis. Wanita hamil dengan COVID-19 memiliki kemungkinan lebih rendah untuk memiliki gejala klinis jika dibandingkan dengan populasi wanita usia reproduktif dengan COVID-19 yang tidak hamil (OR=0,28; 95\%IK=0,13-0,62; 4 studi sebanyak 462.051 sampel), atau timbul gejala demam, sesak, dan nyeri otot. ${ }^{19}$

Apabila dibandingkan dengan wanita hamil yang tidak terinfeksi SARS-CoV-2, terdapat peningkatan risiko kematian $(\mathrm{OR}=2.85 ; 95 \% \quad \mathrm{IK}=1,08-7,51 ; 8$ studi sebanyak 4.820 sampel) dan peningkatan kemungkinan dirawat di ruang intensif $(\mathrm{OR}=18.58 ; 95 \% \mathrm{IK}=7,53-45,82 ; 7$ studi sebanyak 4.990 wanita) pada wanita hamil dengan COVID-19. Risiko kelahiran preterm dan bayi yang lahir dalam keadaan meninggal dunia juga lebih tinggi pada wanita hamil dengan COVID-19. ${ }^{19}$

Angka kematian ibu yang terinfeksi SARS-CoV-2 ketika gelombang pertama pandemi di Amerika Serikat tidak berbeda dengan wanita yang tidak hamil. Dalam kehamilan, sistem imun tubuh mengalami sejumlah perubahan yang sebagian berhubungan dengan perubahan kadar hormon. Karakteristik sistem imun wanita hamil adalah toleransi imun antiinflamasi. Penyakit autoimun umumnya mengalami remisi saat kehamilan, dan flare akan muncul dalam periode postpartum. Pada kelompok ibu hamil dengan COVID-19 asimtomatik atau dengan simtom yang minimal, dijumpai perbedaan profil sistem imun jika dibandingkan dengan kelompok pasien hamil tanpa infeksi SARS-CoV-2. Kadar Platelet Derived Growth Factor-AA (PDGF-AA) dan Epidermal Growth Factor (EGF) meningkat pada pasien hamil dengan COVID-19. Peningkatan PDGFAA terkait dengan remodelling vaskuler, memiliki kaitan dengan kadar sitokin IL-4 yang tinggi. EGF berperan dalam respon proliferasi seluler dan penyembuhan. ${ }^{20}$

Konsentrasi kemokin-kemokin seperti CCL4, CCL5, CCL11, CXCL1 dan CXCL2 ditemukan lebih rendah pada ibu hamil. Kemokin-kemokin tersebut memiliki kemampuan untuk menarik monosit, sel $\mathrm{T}$ memori, sel Natural Killer (NK), dan neutrofil ke lokasi infeksi. Kadar CCL4, CCL5, CXCL2 lebih tinggi pada ibu hamil dengan COVID-19. Konsentrasi sitokin antiinflamasi dalam plasma seperti IL-1RA, IL-10, IL-27, dan IL19 lebih tinggi pada ibu hamil dengan COVID-19. Sitokin yang berperan dalam keparahan COVID-19 seperti IL-6 tidak ditemukan meningkat. Molekul PD-L1 yang mengatur keseimbangan antara imunitas protektif dan jejas seluler yang terkait sistem imun meningkat konsentrasinya dalam ibu hamil dengan COVID-19, akan tetapi dengan kadar lebih rendah dibandingkan ibu hamil tanpa COVID-19. Angka D-dimer pasien hamil dengan COVID-19 lebih rendah dibandingkan dengan ibu hamil tanpa infeksi SARS-CoV-2. Jumlah Low-Density Neutrophils (LDN) meningkat dalam sirkulasi wanita hamil dengan COVID-19 asimtomatik. Jika dibandingkan dengan High-Density Neutrophils (HDN), LDN memiliki kapabilitas fagositik lebih rendah, gangguan produksi Reactive Oxygen Species (ROS), dan kehilangan kemampuan untuk menghambat proliferasi sel $\mathrm{T}$ CD8+. LDN memiliki kapasitas antiinflamasi yang dimediasi oleh ekspresi arginase, menyebabkan regulasi turun dari respon limfosit. Respon imun limfosit Th1 dapat membahayakan fetus, dan LDN menyebabkan respon imun limfosit bergeser ke fenotif Th2. Keseluruhan kondisi imunosupresif dan perubahan modulasi respon imun pada wanita hamil dapat menimbulkan efek protektif terhadap badai sitokin dan keadaan hiper inflamasi. ${ }^{20}$

Rasio dan persentase kematian ibu akibat infeksi SARS-CoV dan MERS$\mathrm{CoV}$ jauh lebih tinggi dibandingkan dengan infeksi SARS-CoV-2. Gejala COVID-19 berat yang menyertai ARDS berhubungan erat dengan peningkatan kadar sitokin proinflamasi IL-6 dan TNF$\alpha$. Kehamilan memiliki tiga fase respon imunologis, yakni fase proinflamasi saat awal kehamilan, antiinflamasi hingga akhir kehamilan dan proinflamasi ketika periode peripartum dan postpartum. Kondisi proinflamasi ditandai dengan dominasi Th1 dan Th17, produksi berlebih dari sitokin proinflamasi IL-1 $\beta$, IL-6, IL-8, IL-12, TNF- $\alpha$, IFN- $\gamma$. Fase antiinflamasi didominasi oleh Th2 dengan peningkatan produksi sitokin antiinflamasi IL-4, IL-5, IL-10, IL-13 dan TGF- $\beta$. Hormon plasenta seperti estriol, estradiol, progesteron, Human Chorionic Gonadotropin (hCG) dalam kehamilan memiliki kemampuan untuk mengamplifikasi respon Th2 dan mencegah sekresi sitokin yang dipicu oleh Th1. ${ }^{20}$

Perubahan respon imun yang didominasi oleh Th1 menjadi Th2 diperantarai oleh IL-10 dan Macrophage Colony-Stimulating Factor (M-CSF). Respon imun seluler yang semula didominasi oleh makrofag M1 juga mengalami pergeseran menjadi makrofag M2, memproduksi IL-10 dan TGF- $\beta$ dalam jumlah besar yang pada akhirnya semakin memperkuat respon antiinflamasi dan pemulihan jejas jaringan. ${ }^{20}$

Perbedaan utama antara respon imun tubuh manusia terhadap infeksi SARS-CoV dan SARS-CoV-2 yang dapat menjelaskan mengapa infeksi SARSCoV-2 pada wanita hamil lebih tidak fatal adalah respon imun tubuh terhadap SARS-CoV-2 akan mengaktifkan mediator proinflamasi (Th-1) dan antiinflamasi (Th-2) sekaligus, sedangkan SARS-CoV dan MERS-CoV memicu aktivasi respon imun Th-1 saja. ${ }^{21}$ Oleh karena itu, aktivasi imunitas Th-1 dan Th-2 yang bersamaan dalam kasus COVID-19 berpotensi tidak menyebabkan badai sitokin pada wanita hamil yang telah memiliki imunitas Th-2 yang dominan. Kadar IL-10 meningkat drastis dalam seluruh periode kehamilan karena diproduksi oleh berbagai sumber seperti trofoblas, sel NK uterus dan monosit. IL-10 memiliki efek antiinflamasi dan antifibrotik di paru dan jaringan tubuh lainnya melalui supresi imunitas Th-1. Produksi antibodi oleh sel limfosit B juga meningkat karena sintasan limfosit B diperpanjang oleh IL-10. ${ }^{21}$

$\begin{array}{ccc}\begin{array}{c}\text { Progesteron } \\ \text { meningkatkan }\end{array} & \text { secara } & \text { fisiologis } \\ \text { produksi } & \text { sitokin- }\end{array}$ sitokin Th-2 untuk melindungi proses kehamilan. Konsentrasi progesteron meningkat melalui plasenta, menstimulasi sintesis Progesterone-Induced Binding Factor (PIBF) dalam limfosit, memicu diferensiasi sel-sel Th-1 menjadi Th-2. ${ }^{21}$ Progesteron juga meningkatkan kadar IL-10 dalam sirkulasi. Hormon estrogen, terutama estradiol (E2) dan estriol (E3) juga memiliki aksi imunomodulasi 
dan antiinflamasi dalam kehamilan. Konsentrasi estriol meningkat hingga 1000 kali lipat dan estradiol hingga 100 kali lipat saat kehamilan. Estradiol meningkatkan produksi sitokin antiinflamasi IL-10 dan IL-5, menurunkan produksi sitokin proinflamasi seperti TNF- $\alpha$. Peningkatan kadar estradiol dan striol akan memicu respon Th-2 dan imunitas humoral. ${ }^{21}$

Kelemahan penelitian ini yang diketahui oleh peneliti antara lain metode uji antibodi terhadap SARS-CoV-2 yang tidak seragam, jumlah sampel yang sedikit, serta jenis primer dan reagen RT-PCR yang digunakan tidak seragam untuk semua sampel. Sisi kekuatan dari penelitian ini adalah penggunaan primer yang spesifik terhadap SARS-CoV-2 menghilangkan kemungkinan infeksi oleh virus korona lain, kombinasi antibodi terhadap SARS-CoV-2 dengan nilai CT dapat memperkirakan periode infeksi, dan menunjukkan bahwa keparahan penyakit dalam populasi wanita hamil tidak ditentukan oleh jumlah RNA dalam sampel.

\section{SIMPULAN}

Nilai CT pada wanita hamil dengan COVID-19 asimtomatis beragam tergantung primer yang digunakan dimana memiliki rentang 17,66-41,28. Sebagian kecil pasien memiliki kemungkinan tengah dalam fase infeksi akut, sedangkan mayoritas memiliki kemungkinan berada dalam akhir fase akhir infeksi akut hingga awal fase konvalesen. Sebagian besar pasien dalam akhir fase infeksi akut hingga konvalesen masih memiliki kemungkinan terdapat virus yang aktif dan viabel untuk dilakukan kultur. Pasien dengan probabilitas tinggi hasil kultur virus positif dan terdeteksi antibodi IgM serta IgG terhadap SARS-CoV-2, memerlukan perawatan isolasi selama setidaknya 10 hari. Pasien dengan probabilitas rendah hasil kultur virus positif dan terdeteksi antibodi IgG terhadap SARS-CoV-2 tidak memerlukan perawatan isolasi di fasilitas kesehatan rujukan dan dapat menjalani isolasi mandiri.

\section{KONFLIK KEPENTINGAN}

Tidak terdapat konflik kepentingan dalam penulisan laporan penelitian ini.

\section{ETIKA PENELITIAN}

Penelitian ini telah mendapatkan persetujuan dari Komisi Etik Fakultas Kedokteran Universitas Udayana, RSUP Sanglah, Bali, Indonesia disertai dengan persetujuan tertulis (informed consent) sebelum penelitian berjalan.

\section{PENDANAAN}

Penulis bertanggung jawab terhadap pendanaan penelitian ini tanpa melibatkan pihak sponsor, beasiswa, ataupun sumber pendanaan lainnya.

\section{KONTRIBUSI PENULIS}

Seluruh penulis memiliki kontribusi yang sama dalam penulisan laporan penelitian ini baik dari tahap penyusunan kerangka konsep, pengumpulan data, analisis data penelitian, hingga interpretasi hasil penelitian dalam bentuk publikasi ilmiah.

\section{DAFTAR PUSTAKA}

1. She J, Jiang J, Ye L, Hu L, Bai C, Song Y. 2019 novel coronavirus of pneumonia in Wuhan, China: emerging attack and management strategies. Clin Transl Med. 2020;9(1):19.

2. Cucinotta D, Vanelli M. WHO Declares COVID-19 a Pandemic. Acta Biomed. 2020;91(1):157-160.

3. Hikmawati I, Setiyabudi R. Epidemiology of COVID-19 in Indonesia: common source and propagated source as a cause for outbreaks. J Infect Dev Ctries. 2021;15(5):646-652.

4. Touma M. COVID-19: molecular diagnostics overview. J Mol Med (Berl). 2020;98(7):947954.

5. $\mathrm{Wu} \mathrm{Z}, \mathrm{McGoogan}$ JM. Characteristics of and Important Lessons From the Coronavirus Disease 2019 (COVID-19) Outbreak in China: Summary of a Report of 72314 Cases From the Chinese Center for Disease Control and Prevention. JAMA. 2020;323(13):1239-1242.

6. Lee S, Kim T, Lee E, Lee C, Kim H, Rhee $\mathrm{H}$, et al. Clinical Course and Molecular Viral Shedding Among Asymptomatic and Symptomatic Patients With SARS-CoV-2 Infection in a Community Treatment Center in the Republic of Korea. JAMA Intern Med. 2020;180(11):1447-1452.

7. Rao SN, Manissero D, Steele VR, Pareja J. A Systematic Review of the Clinical Utility of Cycle Threshold Values in the Context of COVID-19. Infect Dis Ther. 2020;9(3):573-586.

8. Rhee C, Kanjilal S, Baker M, Klompas M. Duration of Severe Acute Respiratory Syndrome Coronavirus 2 (SARS-CoV-2) Infectivity:
When Is It Safe to Discontinue Isolation?. Clin Infect Dis. 2021;72(8):1467-1474.

9. Tom MR, Mina MJ. To Interpret the SARSCoV-2 Test, Consider the Cycle Threshold Value. Clin Infect Dis. 2020;71(16):2252-2254. doi:10.1093/cid/ciaa619

10. Young BE, Ong SWX, Kalimuddin S, Low JG, Tan SY, Loh J, et al. Epidemiologic Features and Clinical Course of Patients Infected With SARSCoV-2 in Singapore. JAMA. 2020;323(15):14881494.

11. Dashraath P, Wong JLJ, Lim MXK, Lim LM, Li S, Biswas A, et al. Coronavirus disease 2019 (COVID-19) pandemic and pregnancy. Am J Obstet Gynecol. 2020;222(6):521-531.

12. Ortiz EI, Herrera E, De La Torre A. Coronavirus (COVID 19) Infection in Pregnancy. Colomb Med (Cali). 2020;51(2):e4271.

13. Seegene. Allplex ${ }^{\mathrm{TM}}$ 2019-nCoV Assay. Instructions for Use (IFU). 2021. [Dapat diakses pada: http://www.seegene.com/upload/ product/IFU_FDA_COVID19_Seegene.pdf]

14. SolGent. DiaPlexQTM Novel Coronavirus (2019-nCoV) Detection Kit. Instructions for Use (IFU). 2021. [Dapat diakses pada: https:// www.fda.gov/media/138303/download]

15. BioFarma. mBioCov-19 RT-PCR Kit. E-Katalog Indonesia. 2021. [Dapat diakses pada: https://e-katalog.lkpp.go.id/katalog/produk/ detail/1255987? lang=en\&type $=$ general $\backslash$ ].

16. SD Biosensor. STANDARD $\mathrm{M}$ nCoV RealTime Detection kit. Instructions for Use (IFU) 2021. [Dapat diakses pada: https://www.fda. gov/media/137302/download].

17. Galipeau Y, Greig M, Liu G, Driedger M, Langlois MA. Humoral Responses and Serological Assays in SARS-CoV-2 Infections. Front Immunol. 2020;11:610688.

18. Metz TD, Clifton RG, Hughes BL, Sandoval G, Saade GR, Grobman WA, et al. Disease Severity and Perinatal Outcomes of Pregnant Patients With Coronavirus Disease 2019 (COVID-19). Obstet Gynecol. 2021;137(4):571580.

19. Allotey J, Stallings E, Bonet M, Yap M, Chatterjee $\mathrm{S}$, Kew $\mathrm{T}$, et al. Clinical manifestations, risk factors, and maternal and perinatal outcomes of coronavirus disease 2019 in pregnancy: living systematic review and meta-analysis. BMJ. 2020;370:m3320.

20. De Biasi S, Tartaro DL, Gibellini L, Paolini A, Quong A, Petes C, et al. Endogenous control of inflammation characterizes pregnant women with asymptomatic or paucisymptomatic SARS-CoV-2 infection. Nat Commun. 2021;12(1):4677.

21. Berhan Y. What immunological and hormonal protective factors lower the risk of COVID-19 related deaths in pregnant women?. J Reprod Immunol. 2020;142:103180.

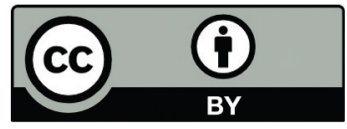

This work is licensed under a Creative Commons Attribution 